\title{
EMPLOYMENT RELATIONS IN INFORMATION TECHNOLOGY INDUSTRY OF INDIA: LEGAL APPROACH
}

\author{
Sidhya Brat Dash \\ Research Scholar, PG Department of Law, Utkal University, Bhubaneswar, India \\ Dr. Madhu Sudan Dash \\ Professor, P.G. Department of Law, Utkal University, Bhubaneswar, India
}

\begin{abstract}
The Information Technology (IT) sector in India has grown exponentially over the years. As the IT sector grows many challenges emerge in the employment relations of IT industry. One of the major challenges faced by employees relates to retrenchment by the employer citing reasons of inefficiency and falling business demands. The recent outbreak of Covid-19 pandemic has posed a greater challenge for the employee of getting forceful termination from their employers. The affected employees have the option of either finding a new job or may fight against unlawful retrenchment. In majority of the cases, it is noticed that, the affected employees do not prefer legal redressal. It is important to find the legal approach to overcome retrenchment for the employees to get protection from employer's coercive action in IT companies. This research paper analyses the existing employment laws and important judicial pronouncements affecting the employment relations in Indian IT Industry.
\end{abstract}

Key words: Employment Relations, Information Technology, Legal Approach, Trade Union, Retrenchment, Covid-19.

Cite this Article: Sidhya Brat Dash and Dr Madhu Sudan Dash, Employment Relations in Information Technology Industry of India: Legal Approach, International Journal of Management, 11(12), 2020, pp 703-716.

http://iaeme.com/Home/issue/IJM?Volume $=11 \&$ Issue $=12$

\section{INTRODUCTION}

In India post liberalization of 90's has given the opportunity to industries to do business in digital platform. This has resulted in the growth of IT companies capitalizing the digital space. The success of this growth has continued in last three decades. The new liberal economy has helped the IT companies to grow in an unregulated market scenario where the employer and employee felt free to exercise their right to execute employment contract of their choice. The significant growth in IT sector happened because of the support of the 
National and State Government and flexible implementation of labour laws. The majority of workforces working in the IT industry are young and skilled and each year lakhs of students are getting recruited by the IT employers from various engineering colleges through campuses interviews.

The hiring and termination of the employees are essentially driven by markets. In a recession market Scenario the employer prefer to reduce work force through mass retrenchments business demand use to demand use to fall. Similarly, in a flourishing market scenario employer and employee are free to take decisions of their choice like employers prefer bulk hiring of employees and employee prefer to join a company of his or her choice. In both these scenario both employer and employee enjoys the freedom of exercising their contract obligation which was flexible in nature. The understanding was working well until the problem of mass retrenchment emerges strongly in the IT industries. The continuous use of retrenchment by the employer of the IT industry has not only impacted the employment relationship but it has also affected the fundamental right of the employee. This menace of mass retrenchment by companies has created a fear psychosis among the IT professionals. The issue of job security has become a major concern for the employee of an IT industry. Here, comes a fundamental question with respect to the right of the employees which is getting affected because of the flexibility in employment relationship. In a welfare state like India which runs on the principles of Socialist democratic norms, can we afford to continue with this problem?

Unlike manufacturing sector which are dominated by trade union, IT sector are mostly non- unionized. The employees have limited opportunity of using collective bargaining to fight against employer coercive action. The concept of "Collective bargaining" was defined by the Supreme Court as "the technique by which disputes as to conditions of employment are resolved amicably by agreement rather than coercion".[1]' In majority of the cases employers of IT companies execute forced retrenchment without following the process prescribed and established by law. This goes against the spirit of labour and employment protection laws guaranteed to an employee working in any establishment or industry. It also goes against the fundamental right of the employee guaranteed under the following Articles of the Constitution of India to live a dignified life.

Article 14 The State shall not deny to any person equality before the Law and equal protection of laws.

Article 21 No person shall be deprived of his life or personal liberty expect according to procedure established by Law.

In India there are several laws that are enacted on employee protection but the two important legislations which are regulating the employment relationship of IT industry are: (i) the Industrial Dispute Act, 1947 (IDAct) and the state relevant Shops and Commercial Establishment Act(S\&CEAct). The IT industry in India is regulated by the Shops and Commercial Establishment Act. Every State in India has its own Shops \& Commercial Establishment Act. The Act has laid down provisions regarding procedures to be followed for termination. However, IT companies seldom follow these regulations in practice while terminating employees. The recent outbreak of Covid-19 has badly impacted the IT companies and resulted in significant business loss. In these circumstances employees are apprehensive and fearful of getting terminated by the employer. The government has brought various guidelines to stop forcible retrenchment of employees but it is important to see whether these measures will stop retrenchment in future.

The present research analysis will revolve round the existing State legislations on employee's protection and judicial approach to protect employees from "retrenchment" which 
are relevant to IT industry. The role of Judiciary in cases of retrenchment has been very positive for employees.

\section{RETRENCHMENT PROVISIONS IN LABOUR LAWS}

In India industries are categorized as establishment and factories. The industries in India are regulated by a number of regulations, but in the matter of retrenchment three important statutes have clear provisos namely the Industrial Dispute Act of 1947, the Shops and Commercial Establishment Act and the Industrial Employment (Standing Order Act) of 1946. All the employees in general working in manufacturing establishments or non-manufacturing establishments are governed and protected by these regulations. The employees who are working in the manufacturing units are addressed as "workmen". As per the provisions of section 2(s) of IDA at of 1947 the definition of workmen is given as:

"workmen" means any person(including an apprentice) employed in any industry to do any manual, skilled, technical, operational, clerical or supervisory work for hire or reward, whether the terms of employment be expressed or implied, and for the purpose of any proceeding under this act in relation to an industrial dispute, includes any such person who have been dismissed, discharged or retrenched in connection with or as a consequence of, that dispute, or whose dismissal, discharge or retrenchment has led to that dispute, but does not include any such person- who is subject to Armed forces Act, Police service, Managerial or Administrative capacity, Draws wages more than 10,000 rupees and does duties mainly of a managerial nature.

The employees who are working in the various other establishments are called as 'NonWorkmen'. The employees of IT companies are covered under the Shops and Commercial Establishment Act which varies from State to State.[2] However, in some employment disputes the Hon'ble Courts have pronounced the employee of IT companies as "workmen" and given relief as per the provisions of IDA Act, 1974. In India both the Central and State Governments have concurrent powers to legislate on labour and employment laws, as per the respective requirements. The provisions on retrenchment/termination are mentioned in laws of both Central and State Governments. Some of the important provisions on termination within the ambit of labour laws are as follows:

1. As per the provision of Industrial Dispute Act, 1947, employers before terminating an employee with a continuous service of one year have to give one of month notice and have to cite the reasons of termination in writing. In case of termination, wages equivalent to 15 days of average pay to be given to the employee for each completed year of service in lieu of notice period. As per provisions of Sec 25G of Industrial Dispute Act, 1947

"Procedure for retrenchment.- Where any workmen in an industrial establishment, who is a citizen of India, is to be retrenched and he belongs to a particular category of workmen in that establishment, in the absence of any agreement between the employer and the workmen in this behalf, the employer shall ordinarily retrench the workmen who was the last person to be employed in that category, unless for reasons to be recorded the employer retrenches any other workmen".

Section 25N of Industrial Dispute Act, 1947 has laid down the conditions of retrenchment as: a. No workman employed in any industrial establishment to which this chapter applies, who has been in continuous service for not less than one year under an employer shall be retrenched by the employer until-

- the workman has been given there months' notice in writing indicating the reasons for the retrenchment and the period of notice has expired, or the workman has been paid in lieu of such notice, wages for the period of the notice; and 
- the prior permission of the appropriate government or such authority as may be specified by that Government by notification in the official Gazette (specified authority) has been obtained on an application made in this behalf.

b. Where an application for permission under sub-section (1) has been made, the appropriate Government or the specified authority, after making such enquiry as it thinks fit and after giving a reasonable opportunity of being heard to the employer, the workmen concerned and the person interested in such retrenchment, may, having regard to the genuineness and adequacy of the reasons stated by the employer, the interests of the workmen and all other relevant factors, by order and for reasons to be recorded in writing, grant or refuse to grant such permission and a copy of such order shall be communicated to the employer and the workmen.

c. Where no application for permission under sub-section (1) is made, or where the permission for any retrenchment has been refused, such retrenchment shall be deemed to be illegal from the date on which the notice of retrenchment was given to the workman and the workman shall be entitled to all the benefits and any law for the time being in force as if no notice has been given to him.

d. Where permission for retrenchment has been granted under sub-section(3) or where permission for retrenchment is deemed to be granted under sub-section(4), every workman who is employed in that establishment immediately before the date of application for permission under this section shall be entitled to receive, at the time of retrenchment, compensation which shall be equivalent to fifteen days' average pay for every completed year of continuous service or any part thereof in excess of six months.

2. Provisions with respect to termination of an employee have been provided under the S\&CE Act. The Orissa Shops and Commercial Establishment Act, 1956 provides that the service of the employee cannot be terminated without thirty days notice for such termination or in lieu of such notice the employer has to pay wages for one month calculated at the rate payable on the date of the notice of the termination of service. The said law differs from State to State. Other States have similar provision on termination in the S\&CE Act unless in case of misconduct.

3. Section 13. of the Industrial Employment Standing Order act, Central Rules of 1946 has given the provision for termination of an employee which says :

"Termination of services (a) For terminating the services of permanent workmen having less than one year of continuous service, notice of one month in writing with reasons or wages in lieu thereof shall be given by the employer: Provided that no such notice shall be required to be given when the services of the workmen are terminated on account of misconduct established in accordance with the Standing Orders".

\section{RETRENCHMENT PROVISIONS IN INTERNATIONAL LABOUR LAW}

The termination of an employee under the International Labour Organisation, Employment Convention of 1982(No. 158) has laid down provisions for the protection of employees against termination. Some of the important provisions are as follows:

Article 4 of the international convention has give the condition of termination "The employment of a worker shall not be terminated unless there is a valid reason for such termination connected with the capacity or conduct of the worker or based on the operation requirements of the undertaking, establishment or service".

Article 11 of the convention has given conditions of notice served to employee in case of termination "A Worker whose employment is to be terminated shall be entitled to a reasonable period of notice or compensation in lieu thereof, unless he is guilty of serious 
misconduct, that is, misconduct of such a nature that it would be unreasonable to require the employer to continue his employment during this notice period."

Article 15 of the convention is very important which says

"This convention shall be binding only upon those members of the International Labour organization whose ratification have been registered with the Director General."

The recommendations made by the committee of the experts are recommendatory in nature and those countries that had ratified the convention are advised to follow the convention regulations in making national legislations.

Articlel of the convention says

"The provisions of this convention shall, in so far as they are not otherwise made effective by means of collective agreements, arbitrations award or court decisions or in such manner as may be consistent with national practice, be given effect by laws or regulations."

Here, it is important to note that India has not ratified the convention. However, the provisions as mentioned in the International convention No. (158) are already present in our employment protection laws of our country and the laid down principles are reflected in all judicial pronouncements.

\section{LEGAL INTERPRETATION OF "RETRENCHMENT"}

Indian Judicial system has given legal interpretations through various judgments in the matters of retrenchment of employees by employers because of "misconduct", "Inefficiency" and "citing no reasons". Some of the judicial decisions on the issue may be referred as follows:

\section{K Ramesha v. HCL Technologies[3]}

In this case, the Additional Labour Court Presiding Officer S. Nambirajan, 2016, the Hon'ble Labour Court judgment had made it tough for the IT companies to terminate employees at will. In the instant case, Mr. K Ramesha a senior service programmer working with HCL technologies was dismissed on the ground of non performance. He sought relief from the court for wrongful termination. The court in this matter recognized the employee as a "Workmen" in contrast to the claim of the HCL management that, he is a supervisor and doesn't fall under the definition of workmen. The court observed that as per the provisions of the Industrial Dispute Act, 1947 the employee's current responsibility involves skill and the employee can be treated as a workmen. The management of the HCL Company failed to produce any concrete evidence on the grounds of dismissal. In view of this the court declared the dismissal as unlawful and ordered the company to give reemployment to the employee with back wages. The Honb'le Court has given protection to the aggrieved employee in view of the provisions of the Industrial Dispute Act of 1947. The present case has created a judicial precedent for the future employment disputes and protects the employee against employer's coercive action.

\section{Sasirekha Thangavel Natarajan v. Labour Court-III[4]}

In the present case, the Hon'ble Madras High Court has extended relief to the aggrieved employee by passing "an order of interim injunction for a period of four weeks restraining the second respondent from giving effect to the order of termination of service of the petitioner dated 22.12.2014, pending disposal of the writ petition". The aggrieved employee was working as Assistant Software Consultant since 2011 in Tata Consultancy limited, Chennai. The employer dated $22^{\text {nd }}$ December 2014 terminated the service of the employee. Initially, the aggrieved employee appealed before the Labour Court and against the order of the Court the 
employee appealed before the Hon'ble High Court contending that, the company as a 'industry' and within the scope of Sec.2 (j) and Sec. 2(a) of the Industrial Tribunal Act of 1947 the employee can be declared as a 'workwoman'. In response to the stay of the Hon'ble court the company revoked the termination order of the aggrieved employee. In this case the Hon'ble High Court has recognized the employee as a "Workmen.

\section{Visvesvarya Industrial v. Mr. Dilip Madhavrao Vaidya[5]}

The Hon'ble High Court had upheld the Labour Court decision and given relief to the employee. In this case the employee was terminated by the employer on the grounds of nonperformance. The aggrieved employee took the matter to the Labour Court and sought relief against the employer under unfair labour practices under Item 1(b) and 1(d) of Schedule IV provisions of the Maharashtra Recognition of Trade unions and Prevention of Unfair labour Practices Act of 1971(MRTU\&PULP Act). The Hon'ble Court observed no domestic enquiry was followed before the termination and principle of natural justice was not followed. In view of this the Hon'ble court ordered for the reinstatement of the employee with back wages and held the termination by the employer as illegal. In the case of Madan Mohan v. State of Bihar [6], the Hon'ble Court observed that terminating the services of an employee on the ground of unsatisfactory work without any enquiry lead the public to believe that the employment have been terminated on account of inefficiency or misconduct without holding enquire as per established law and this does cast a stigma on his character.

\section{Dr. Mrs. Sumati P. Shere V Union of India (Uoi) and Ors.[7]}

In the present case, the Hon'ble Court on 3 April, 1989, has set aside the termination order of the employer saying that in cases of non performance the employee have to be informed in advance about her non performance and her service may not be required for the employer.

\section{Miss T. N. Chandra V .South India Corp(Agencies) Ltd. [8]}

In this case the Hon'ble High Court held that the employee was terminated on the grounds of unsatisfactory conduct and no notice was issued to him before termination. The Hon'ble Court also said on 13 February, 1991 that there was no sufficient or proper compliance of Section 41(1) of the Tamil Nadu Shops \& Commercial Establishment Act of 1947 and consequently the issue of termination order cannot be upheld. In this case the counsel for the respondent has stressed on the judgment reported in Mohan Lal v. Bharat Electronics Ltd. [9] the Supreme Court held that a termination in contravention to Section 25 of the Industrial Dispute Act of 1947 would be 'ab initio' void and the workmen is entitled to reemployment with all 'consequential benefits'. In Krishna District C. M. Society Ltd. Vijaywada Versus N. v. P. Rao and Others [10] the Hon'ble Supreme Court held that if an employee treated as 'Workmen' as defined in the Industrial Dispute Act of 1947 and the termination of employee amounts to 'retrenchment' then it invites the provisions of Chapter V-A of the Industrial Dispute Act of 1947 and Section 40(1) and (3) of the Andhra Pradesh Shops and Establishment Act, 1966. An aggrieved employee can take legal remedy of both these laws.

\section{Jayanti Raojibhai Pate V. Municipal Council, Narkhed \& Ors[11].}

This is a recent judgment pronounced by Hon'ble Supreme court of India on wrongful termination of employee the court held that, in case of wrongful termination the employee is entitled to get re-employment with back wages from the period of termination. 


\section{Tapash Kumar Paul V. BSNL \& Ors., Hindustan Tin Works V. Employees and Deepali Gundu Surwase V. Kranti Junior Adhyapad Mahavidyala.[12]}

In all these matters the Hon'ble Supreme Court has reiterated the position on 'termination' and submitted that if the termination is done which violates the provisions of Section-25 of the Industrial Dispute Act of 1947 then the employee is entitled to be reinstated with back wages.

\section{Jagbir Singh V. Haryana State Agriculture Marketing Board[13]}

In this matter the Hon'ble court has laid down different factors for consideration in determining compensation in cases of illegal termination. These factors are mainly the method of appointment, nature of employment and length of employment. This judgment has given clear norm in the determination of compensation given to employees in case of illegal termination. The court also held that reinstatement of workmen is not possible in all cases where it is declared as illegal and go against the provisions of Section 25(F) of the Industrial Dispute Act, 1947.

\section{Utter Pradesh Satte Brassware Corposration Ltd. V.Uday Narayan Pandey[14]}

The case was related to illegal retrenchment of workmen in violation of the UP Industrial Dispute Act, 1947. In this matter the Hon'ble court held that,

"Although according to the learned counsel appearing on behalf of the appellant Labour court and the High court committed an error in the arriving at a finding that in terminating the services of the respondent, the provisions of Section $6 \mathrm{~N}$ of the UP Industrial Dispute Act were contravened, we will proceed on the basis that the said finding is correct. The question however would be as to whether in a situation of this nature, relief of reinstatement in services should have been granted. It is now well settled by reasons of catena of decisions of the court that the relief of reinstatement with back wages would not be granted only because it would be lawful to do so. For the said purpose, several factors are required to be taken into consideration, one of them being as to whether such an appointment had been made in terms of statutory rules. Delay in Industrial dispute is also a relevant fact."

\section{M/S Deccan Charters Private V. Sarita Tiwari[15]}

In this case the Hon'ble court held that a probationer can be terminated during the probation period then the termination would not be considered to be a case of a 'workman' and doesn't invite the scope of section 2(S) of the Industrial Dispute Act of 1947. Such termination does not amount to retrenchment as mentioned in section2 (oo) of the IDA act, 1947.

\section{Venugopalan V. Divisional Manager[16]}

In this matter the Hon'ble court held that the termination of a probationer before the completion of probation is not a case of 'retrenchment' and fall outside the scope of Section2 (oo) (bb) of the Industrial Dispute Act of 1947.

\section{Mahinder Singh vs M/S. Indian Airlines Ltd[17]}

In this case the Hon'ble court held that if probationer is terminated in consonance to the terms of the contract then in that case it would not be considered as a case of "retrenchment" provisions of Industrial Dispute Act of 1947 does not apply to it. The court did not consider the request of the petitioner to treat him as 'workmen' as per the definition of Section(s) of the IDA Act 1947. 
The Hon'ble Supreme Court in the matter of Olga Tellis V. Bombay Municipal Corporation [18] held that the person's right to life and liberty guaranteed under Art. 21 of the constitution also guarantees right to livelihood. These important judicial pronouncements on retrenchment of employees have given a different dimension to definition of "retrenchment" as laid down in the section 2(oo) of the Industrial Dispute Act of 1947 and played a significant role in the enforcement of labour law for the employee's given an opportunity to reduce the legislative gap.

\section{ANALYSIS}

There are three intertwined dimensions which affect the employment relations in Information Technology Industry. The first dimension relates to the change in business scenario which impacts the employment relations in IT industry. The demand and supply of manpower in IT sector is invariably being regulated by the markets. The employer of IT the industry always prefers to make employment contracts which can serve their business interest. The decision of the IT companies to go for massive retrenchment is an evidence of the flexible employment contract. According to Andrew Stevens work and employment in both developed and developing countries have accepted the practice of hire and fire, fexi wage labour market policies to make profit and increase productivity[19]. In the early 90s's economic liberalisation has brought a significant change in the employment relations of the past and broken the status quo which was existing in the pre liberalised era. It is generally observed that, in a profit making market scenario IT companies stays away from retrenchment of employees. However, in a recession market scenario they go for initial selective and later large scale retrenchment of employees to eliminate or minimize losses. In such events the fundamental right of the employee guaranteed under Article 21(Right to Livelihood) is curtailed and it also affects the fundamental principles laid down in Directive Principles of State Policy enshrined in the Constitution of India which guarantees adequate livelihood to all the citizens of India.

Article 39 of Directive principle of state Policy state that "The State shall, in particular, direct its policy towards securing- (a) that the citizens, men and women have the right to an adequate means of livelihood."

In India the employees of IT industries are governed by the Shops and Commercial Establishment Act, but Hon'ble Courts while giving judgments in employment matters have relied upon the sections of the Factories Act of 1948 and Industrial Dispute Act of 1947 and given relief to the employees under the provision of both the laws. In one of the cases Hon'ble Bombay High Court has categorized Information Technology companies and Software Development Firms as 'factories'. "The development and creation of software has been considered as a process of manufacturing and the establishment where the computers are used in the manufacturing process has been considered as 'factory' for the purpose of the Employees' State Insurance Act of 1948"[20]'In the case of Seelan Raj, [21] the Hon'ble Madras High Court has observed that "an electronic data processing unit or computer unit installed in any premises or part thereof, and such activities may amount to manufacturing process, bringing within the ambit of 'factory' as defined under Section 2(m) of the Factories At of 1948, yet Explanation II grants an exemption immunity to electronic data processing or computer unit from being within the purview of the welfare legislation namely the labour laws". Supreme Court in TCS v. State of Andhra Pradesh [22] held that software was goods and hence transactions relating thereto could only be construed as sale of goods.[23] In the case of K Ramesha v. HCL Technologies [24], the Honorable Court has relied upon the provisions of Industrial Dispute Act, 1947 in pronouncing judgment. From these cases it is 
evident that, because of legislative gap the Judiciary has given different legal interpretation to the employment relation of IT industry.

The second dimension which impacts the employment relations in IT industry is with respect to the provision of law and judicial principles which give upper hand to the employer to retrench employee "at will". This is a common practice in the private sector enterprises where employer and employee had "at will" agreement where both the parties can terminate services at will by giving notice of one month's time. Flexibility in the employment contracts encourages the employer to go for massive retrenchment of employees "at will". The Governments is also a facilitator in this process as enforceability of labour laws are weaker in comparison to other industries which gives upper hand to the employers of IT industry to dominate the employment relationship. The provision of Section 2 (oo) in the Industrial dispute Act of 1947 envisages that

"retrenchment means the termination by the employer of the service of the workmen for any reason whatsoever, otherwise than as a punishment inflicted by way of disciplinary action, but does not include--

(bb) "termination of the service of the workmen as a result of the non renewal of the contract of employment between the employer and the workmen concerned on its expiry or of such contract being terminated under a stipulation in that behalf contained therein".

The above provision has given an opportunity to the employer to convert employment contracts into fixed term appointments to retrench employees at convenience. In the matters of Punjab SEB v. Darbara Singh[25] ; National Small Industries Corporation v. Laxminarayan [26]; Punjab SEB v. Sudesh Kumar Puri[27], the Hon'ble Court held that, the workmen engaged on contractual basis against a permanent post should not be covered under the provisions of Section 2(oo) of the Industrial Dispute Act of 1947. The Apex Court in the case of Kishore Chandra samal V The D.M,Orissa State Cashew Development Corporation Ltd.[28] held that long term appointments converted to fixed term appointment did not fall under the provisions of Section 25 (F) of Industrial Dispute Act, 1947. In the case of The Managing Committee of Shiksha Bharati Secondary Public school V. Director of Education $\&$ Ors [29] the Hon'ble court held that termination order of a probationer on the basis of performance issue is not considered to be stigmatic. In this kind of case the principles of natural justice are not required to be followed in terminating a probationer provided that the termination order is not determined on the basis of an enquiry report. In the matter of U.P State Brassware Corporation Ltd. V. Udai Narayan Pandey [30] the Hon'ble Court observed that payment of back wages in matters of illegal termination has to be dealt differently and no employer should be compelled to give back wages. These legal interpretations go against the welfare of employees as employers will go for temporary appointments to save themselves from legal obligation. The provision under Section $25 \mathrm{~F}$ of the Industrial Dispute Act of 1947 laid down the following on retrenchment of workmen.

"No workmen employed in any industry who has been in continuous service for not less than one year under an employer shall be retrenched by that employer until-(a) the workmen has been given one month's notice in writing indicating the reasons for retrenchment and the period of notice has expired, or the workmen has been paid in lieu of such notices, wages for the period of the notice (b) the workmen has been paid, at the time of retrenchment, compensation which shall be equivalent to fifteen day's average pay (for every completed year of continuous service) (c) notice in the prescribed manner is served on the appropriate government(or such authority may be specified by the appropriate government by notification in the Official Gazette)". 
In the provision of Section $25(\mathrm{~F})$, it is generally noticed that IT companies seldom follow these regulations before retrenchment which can be seen in plethora of cases like K Ramesha v. HCL Technologies [31] and Sasirekha Thangavel Natarajan v. Labour Court-III[32]. In such a relatively unregulated employment environment, it would have been unlikely that most employment relationship are formed with some unstated expectation by both parties that a termination would require advance notice, following the prescribed procedure, severance pay, or some form of legal justification.[33] In the matter of State of Bombay and Others V. Hospital Mazdoor sabha \& others[34] the Hon'ble court has given a significant judgment in the interpreting the retrenchment provision of section2(oo) of Industrial Dispute Act of 1947.

“(4) Statutory construction, when courts consider welfare legislation with an economic justice bias, cannot turn on clod print, glorified as grammatical construction, but on telelogical purpose and protective intendment. Section 25F, 25B and 2(oo), of the Industrial Dispute Act, 1947 have a workers' mission and the input of part IV of the constitution also underscores this benignant approach. While cannons of traditional sanctity cannot wholly govern, courts go hay wire in interpreting provisions, ignoring the text and context. Words of multiple import have to be winnowed judicially to suit the social philosophy of statute. Dictionaries are not dictators of statutory construction where benignant mood of a law, and more emphatically, the definition clause furnish a different denotation. Section 2(oo) is the master of the situation and court cannot truncate its amplitude. The word "for any reason whatsoever" in section 2(oo) of the Industrial Dispute Act are very wide and amid of no exception."

In the matter of Tatanagar Foundry co. V. Their Workman [35] the Hon'ble court held that if the employer had 'lay off' employees as per the provisions of section 2 (KKK) of the Industrial Dispute Act ,1947 then it is considered to be valid if it is executed for genuine reasons.

The third dimension which has relevance in the employment relations is with respect to lack of trade union representation in employment disputes. As per the provision under section 2(h) of the Trade Union Act, 1926

"Trade Union means any combination of people, where temporary or permanent termed primarily for the purpose of regulating the relations between workmen and employers or between workmen and workmen or between employers and employers, or for imposing restrictive conditions on the conduct of any trade or business and includes any federation of two or more trade union."

The main objective of trade union was meant to protect the interest of the employees and act as a deterrent to protect the employees from unfair labour practices. Unlike the manufacturing industry where employment disputes are fought by the employee unions, in IT industry it is the Human Resource Department which addresses matter of dispute at individual level. This approach of grievance redressal mechanism in IT industry has given less bargaining power to employees to protect their rights against retrenchment by the employer. The employees of IT industry feel the requirement/presence of employee union in retrenchment proceedings as the retrenchment becomes a tool in the hands of employer and common phenomena for the employer in downsizing workforce. The fundamental rights as guaranteed by the constitution of India through Article 19 has guaranteed to every citizen to form associations and unions. As per the provisions of law there is no restriction on the employees of IT industries to make unions. Freeman and Medoff argue that "the presence of a trade union in the workplace provides the proffered institutional arrangement for providing employees with a genuine voice at the workplace, channeled through a trade union, employee could have a clear and influential voice in the workplace that could not be easily misrepresented by the management". In the past few years, an increase in cases of aggrieved 
IT employees have been turning to the courts to seek relief against indiscriminate layoffs and long working hours.[36] This has resulted in the emergence of trade union like Karnataka State IT/ITES Employees Union, KITU and Union of IT and ITES Employees (UNITE). This movement is spreading to the other states and has marked a significant growth in the trade union practices in the Information Technology Sector in India.

\section{CONCLUSION}

The evolving employment relationship in the IT industry has identified the gaps to be bridged both by the legislature and Judiciary. The number of retrenchment happening in the corporate world amid of covid-19 crisis has posed several questions on the enforceability of labour laws. A balance needs to be brought in the employee job security and employer's business interest. There has to be strong approach in implementation of law in regulating employment relationship. In a welfare state like India where fundamental rights of the citizens enshrined in the Constitution stands supreme, employees of IT industry should get their appropriate benefits. The Government concerned should improve the appropriate regulations in consonance with the provision of labour and employment laws and enforce in letter and spirit so that the employment relationship in the IT industry do not get adversely impacted and employee rights are fully protected. A combination of traditional principles of contract like mutual obligation, trust and legal compliance can bring in a new dimension in the employment relationship.

\section{KEYNOTES}

1. Karol Leather Karamchari Sangathan v. Liberty Footwear Company, (1989) 4 SCC 448

2. Dessler Gary, (2011), Human Resource Management, 12th edition, Pearson page 51

3. K Ramesha V.HCL Technologies Additional Labour Court, 2016

4. Sasirekha Thangavel Natarajan V. Labour Court-III,W.P.No.1057 of 2015and M.P No.1 of 2015(High Court,20/01/2015)

5. M. Visvesvarya Industrial v. Mr. Dilip Madhavrao Vaidya 1997, (1998 (1) BomCR 759

6. Madan Mohan V. State of Bihar (A.I.R. 1973 S.C. 113)

7. Dr. Mrs. Sumati P. Shere V. Union of India (UoI) and Ors.1 (AIR 1989 SC 1431)

8. Miss T.N. Chandra V. South India Corp (Agencies), (High Court, 13/02/1991)

9. Mohan Lal V. Bharat Electronics Ltd. (1981-II-LLJ-70)

10. Krishna District C. M. Society Ltd. Vijaywada Versus N. V. P. Rao and Others (1987-II-LLJ-365)

11. Jayantibhai Raojibhai Patel V.. Municipal Council, Narkhed \& Ors.[Civil Appeal No. 6188 of 2019 arising out of SLP(C) No 8112 of 2019]

12. Tapash Kumar Paul V. BSNL \& Ors (2014(4) SLR 875), Hindustan Tin Works V. Employees. (1979 2SCC80), Gundu Surwase V. Kranti Junior Adhyapad Mahavidyala(2013 10SCC324)

13. Jagbir Singh V.. Haryana State Agriculture Marketing Board (2009 15 SCC327)

14. Utter Pradesh Satte Brassware Corposration Ltd. V.Uday Narayan Pandey J2 2005(10) SC344

15. M/S Deccan Charters Private ... vs Sarita Tiwari W.P.(C) 3422/2014 \& CM No.7040/2014 \& 30976/2019(Delhi High Court 27/08/2019)

16. M. Venugopalan V. Divisional Manager (1994)2SCC 323

17. Mahinder Singh vs M/S. Indian Airlines Ltd LPA 63/2014(Delhi High Court 05/09/2016)

18. Olga Tellis \&OrsV. Bombay Municipal Corporation \&..10 July, 1985

19. Gollan Paul J Voice and the non voive union workplace, Employee relations, the international journal, Vol.No.27 No. 32005 
20. NishithDesai. (n.d.). Nishith Desai Associates: Nishith

Desai. https://www.nishithdesai.com/information/research-and-articles/nda-hotline/nda-hotline-singleview/newsid/1239/html/1.html

21. Seelan Raj And Ors V.Presiding Officer, Appeal(civil) 1300-1301of 1998,(Supreme Court of Inda, $16 / 03 / 2001$

22. Tata Consultancy Sertvices V. State of Andhra Pradesh, Appeal(Civil)2582 of 1998(Supreme court of India,05/11/2004; (2005) 1 SCC 308

23. Businesstoday.in. 2020. Big Layoffs In India's IT Sector: Techies Protest Sacking By Cognizant, Seek Govt Intervention. [Online] Available at: $<$ https://www.businesstoday.in/buzztop/buzztopcorporate/big-layoffs-at-wipro-infosys-cognizant-its-mayhem-in-indias-it-sector/story/251707.html> [Accessed 17 May 2020]

24. Ibid.at 4

25. Punjab SEB V. Darbara Singh $\{(2006)$ ISCC 121$\}$

26. National Small Industries Corporation V. Laxminarayan [(2007) ISCC214]

27. Punjab SEB V. Sudesh Kumar Puri [(2007) 2SCC428]

28. Kishore Chandra Samal v. Orissa State Cashew Development Corporation Ltd(2006) ISCC 253

29. The Managing Committee of Shiksha Bharati Secondary Public school V. Director of Education \& Ors , appeal w.p.(c) 10573/2009 (Delhi High Court,0/09/2013

30. Sate Brassware Corporation Ltd. V. Udai Narayan Pandey (20061 SCC479)

31. Ibid at 9

32. Ibid at. 4

33. Arthur S. Leonard, New Common Law of Employment Termination, New York Law School, Available at: $<$ https://digitalcommons.nyls.edu/cgi/viewcontent.cgi?article=1134\&context=fac_articles_chapters $>$ [Accessed 17 May 2020].

34. State of Bombay and others V. Hospital Mazdoor sabha \& Others(1960) (2) SCR\&66

35. Tatanagar Foundry co.V. Their Workman, 1962 I LLJ382(SC)

36. Christopher, N., 2020. IT Employees Get Nod To Set Up Trade Union In Karnataka. [online] The Economic Times. Available at: <https://economictimes.indiatimes.com/tech/ites/it-employees-getnod-to-set-up-trade-union-in-karnataka/articleshow/61568071.cms?from=mdr $>$ [Accessed 17 May 2020].

\section{REFERENCES}

[1] Dessler Gary, (2011), Human Resource Management, 12th edition, Pearson page 51

[2] Gollan Paul J (2005). Voice and the non voice union workplace, Employee relations, the international journal, Vol.No. 27 No. 3

[3] Arthur S. Leonard, New Common Law of Employment Termination, New York Law School, Available at: https://digitalcommons.nyls.edu/ cgi/viewcontent.cgi? article=1134 \& context= fac_articles_chapters $>$ [Accessed 17 May 2020].

[4] Business today.in. 2020. Big Layoffs In India's IT Sector: Techies Protest Sacking By Cognizant, Seek Govt Intervention. [Online] Available at: $<$ https://www.businesstoday.in/buzztop/buzztop-corporate/big-layoffs-at-wipro-infosyscognizant-its-mayhem-in-indias-it- sector/story/251707. html> [Accessed 17 May 2020].

[5] Business today.in. 2020. Big Layoffs In India's IT Sector: Techies Protest Sacking By Cognizant, Seek Govt Intervention. [Online] Available at: <https://www.businesstoday.in/buzztop/buzztop-corporate/big-layoffs-at-wipro-infosyscognizant-its-mayhem-in-indias-it-sector/story/251707. html> [Accessed 17 May 2020] 
[6] Corporate Finance Institute. 2020. Laid Off - Definition, Reasons, Alternatives To Layoffs. [online] Available at: <https://corporatefinanceinstitute.com/resources/careers/jobs/laid-off/> [Accessed 17 May 2020].

[7] Christopher, N., 2020. IT Employees Get Nod to Set Up Trade Union In Karnataka. [Online] The Economic Times. Available at: <https://economictimes.indiatimes.com/tech/ites/itemployees-get-nod-to-set-up-trade-union-in-

karnataka/articleshow/61568071.cms?from $=$ mdr $>$ [Accessed 17 May 2020].

[8] ETtech.com. 2020. IT's Layoff Crisis May Be Bigger Than 2008 Recession - Ettech. [Online] Available at: $<$ https://tech.economictimes.indiatimes.com/news/corporate/its-layoff-crisismay-be-bigger-than-2008-recession/58691201> [Accessed 17 May 2020].

[9] The Economic Times. 2020. India's IT Sector to Grow 7.7\% In FY20: Nasscom. [Online] Available at: $<$ https://economictimes.indiatimes.com/tech/ites/indias-it-sector-to-grow-7-7-infy20 nasscom/articleshow/74109713.cms> [Accessed 17 May 2020].

[10] Lexology.com. 2020. Termination of Service, Layoffs And Retrenchments | Lexology. [Online] Available at: <https://www.lexology.com/library/detail.aspx?g=873969db-ba744ca3-8cb9-d6f7c86f8860> [Accessed 17 May 2020].

[11] NishithDesai. (n.d.). Nishith Desai Associates: https://www.nishithdesai.com/information /research-and-articles/ nda- hotline/nda-hotline-single-view/newsid/1239/html/1.html.

[12] Dr. Mrs. Sumati P. Shere v. Union of India (UoI) and Ors. AIR 1989 SC 1431

[13] Karol Leather Karamchari Sangathan v. Liberty Footwear Company, (1989) 4 SCC 448

[14] Kishore Chandra Samal v. Orissa State Cashew Development Corporation Ltd (2006) ISCC 253

[15] Madan Mohan v. State of Bihar (A.I.R. 1973 S.C. 113)

[16] National Small Industries Corporation v. Laxminarayan [(2007) ISCC214]

[17] Olga Tellis \&OrsV. Bombay Municipal Corporation \&.. 10 July, 1985

[18] Punjab SEB v. Darbara Singh, (2006) ISCC 121

[19] Punjab SEB v. Sudesh Kumar Puri (2007) 2SCC428

[20] Krishna District C. M. Society Ltd. Vijaywada v.N. V. P. Rao and Others (1987-II-LLJ-365)

[21] Seelan Raj And Ors v. Presiding Officer, Appeal (civil) 1300-1301 of 1998,(Supreme Court of Inda, 16/03/2001)

[22] Tata Consultancy Services v. State of Andhra Pradesh, Appeal (Civil) 2582 of 1998(Supreme court of India, 05/11/2004

[23] Jayantibhai Raojibhai Patel V. Municipal Council, Narkhed \& Ors SLP(C) No 8112 of 2019]

[24] Tapash Kumar Paul V. BSNL \& Ors (2014(4) SLR 875), Hindustan Tin Works V. Employees. (1979 2SCC80), Gundu Surwase V. Kranti Junior Adhyapad Mahavidyala(2013 10SCC324)

[25] Jagbir Singh V. Haryana State Agriculture Marketing Board (2009 15 SCC327)

[26] Tatanagar Foundry co.V. Their Workman, 1962 I LLJ382(SC)

[27] The Managing Committee of Shiksha Bharati Secondary Public school V. Director of Education \& Ors, appeal w.p.(c) 10573/2009 (Delhi High Court,0/09/2013

[28] Sate Brassware Corporation Ltd. V. Udai Narayan Pandey (20061 SCC479)

[29] Utter Pradesh Satte Brassware Corposration Ltd. V.Uday Narayan Pandey J2 2005(10) SC344

[30] M. Venugopalan V. Divisional Manager (1994)2SCC 323 
Employment Relations in Information Technology Industry of India: Legal Approach

[31] M. Visvesvarya Industrial v. Mr. Dilip Madhavrao Vaidya 1997, (1998 (1) BomCR 759

[32] Miss T.N. Chandra v. South India Corp (Agencies), (High Court, 13/02/1991)

[33] M/S Deccan Charters Private vs Sarita Tiwari W.P.(C) 3422/2014 \& CM No.7040/2014 \& 30976/2019(Delhi High Court 27/08/2019)

[34] Mahinder Singh vs M/S. Indian Airlines Ltd LPA 63/2014(Delhi High Court 05/09/2016)

[35] Sasirekha Thangavel Natarajan V. Labour Court-III, W.P.No.1057 of 2015 and M.P No.1 of 2015(High Court, 20/01/2015)

[36] K Ramesha v.HCL Technologies, Additional Labour Court, 2016

[37] Mohan Lal v. Bharat Electronics Ltd. (1981-II-LLJ-70) 